\title{
Challenges of Implementation Digital Learning and Online Collaboration to Teach Pronunciation During the COVID-19 Pandemic in Thailand
}

\author{
Nutprapha K. Dennis* \\ Ubon Ratchathani Rajabhat University (UBRU) \\ Ubon Ratchathani, Thailand \\ *em.pa012@gmail.com
}

\begin{abstract}
This article focuses on the challenges faced by students and teachers while adapting to learning and teaching styles needed to implement and conduct a course completely online instead of in a classroom during a 2-month-summer class at a local university in Thailand during the spread of COVID-19 pandemic. The most urgent plans were training and educating both teachers and students about living and working around the virus, this included working and studying remotely. Choosing a user-friendly learning platform was also another challenge. The digital resources used in English pronunciation class were YouTube, Quizlet, and FlipGrid. The three applications combined and used effectively in Schoology as a user-friendly platform. Moreover, the reflective practice was used to get students' reflection toward online lesson throughout the course. Unfortunately, most teachers at the English department did not have enough time to prepare or adapt to the changes because the mandate was issued to close to the start date of the summer classes. Creating and planning online classes were proving to be absolute challenges. The information and the conclusion of this panel will help educators to prepare and choose the best way to construct a blended online learning classroom in a limited period of time more effectively.
\end{abstract}

Keywords-digital learning, online collaboration, English pronunciation, blended online learning

\section{INTRODUCTION}

As of the day this paper was written, we are still living during the pandemic around the world. Earlier this year, during April-May, 2020, COVID-19 was determined to be a pandemic because it was spreading around Thailand and throughout the world [1].

Normally, the summer break each year for most universities in Thailand is during April-June. However, due to the scheduling chaos caused by the Covid-19 virus an English pronunciation class was open for registration by first year English major students. The course was scheduled during Summer Break period. The class required several digital resources to help students practice in class, but in this situation, the teacher had to transform offline digital learning resources into an online platform for students to access and study remotely from their home.
The discussion in this article will focus on a group of weekend students who enrolled in the pronunciation class during the summer semester while the COVID-19 pandemic was still spreading. The group of students who registered for the class had different language backgrounds. Their careers were also diverse, for example, primary teachers, high school teacher, police officers, soldiers, accountants. Their language competency was varied even though they all had formal English instruction in the past. Their language training did not necessarily include pronunciation skills.

One of the government policies intended to slow down and limit the spread of the virus was to close places where large groups of people gathered. Regular classroom classes at schools were cancelled. All the classes had to shift to online and distance learning [2].

It was an opportunity to manage alternative learning and teaching with digital and online collaboration. Unfortunately, most teachers at the English department did not have enough time to prepare nor adapt their lessons to the changes.

The challenges had started due to a severely limited time to prepare all lessons from onsite classroom to online ones. The most urgent plans were training and educating both teachers and students about living and working around the virus, including working and studying remotely. Wearing masks, sustaining physical distancing and personal hygiene needed prevent the spread of the virus [2].

In this article will discuss about how teachers choose learning tools and online platforms to deliver learning contents to students who were waiting to study from home. The process how teachers choose learning tools and online platforms for the purpose of providing learning resources for students in their remote location to use for their studies. All of this is discussed in this article.

The most important component of the solutions is Educational technology [3]. Schools at all levels need to be dedicated to supporting increased levels of technology in the classroom. The schools can show their commitment by providing the needed hardware and enhancing internet connectivity. They can also expand courses and programs to enhance computer literacy for staff and students. 
Stanley [3] also added that Educational technologies are both a benefit and a hindrance to teachers. The teachers find the set-up and integration of technologies a challenge. After the system is functioning then the benefits are realized. They have access to more data which makes research and preparation easier and quicker. The preparations for both online and offline can be completed at one site. The whole process of updating education technology is a complicated and complex challenge. It begins with the decision of which hardware and software are best for the situation. Then funds must be found in the budget, the logistics to acquire what is ordered and then once it is implemented the process of adapting the curriculum and teaching methods.

The purpose of this article is to identify and present challenges and highlight solutions for those challenges that are experienced by teachers when in the process of integrating new technology in the classroom. The data in this article should provide a discussion of value for teaching staff, administrators, researches, and Education Major Students.

The article begins by introducing digital learning and online collaboration in English classroom, including how to choose digital learning tools and learning platform that best-fit to the students.

Challenges and solutions using technologies in the classroom are presented in the next section. The use of reflective practice as reflective journal entry during online learning and teaching [4], will be discussed before the conclusion with a short summary of the recommendation to assist educators to prepare and choose the best way to construct a blended online learning classroom in a limited of time more effectively.

\section{DigitAl LEARNING}

Florida Virtual School defined, "digital learning" as students learn through resources using all kinds of technology which they can learn anywhere, anytime with their own pace. There are 4 elements mentioned; time, place, path and pace [5].

- Time: In the past and still many places today learning was limited to mostly classroom learning and a small amount of time in a library or doing homework. But thanks to the Internet and devices to access the Internet students can have as much time as their life allows to learn at home or any place where they can access the Internet.

- Place: For the same reason as time for learning has expanded so has place for learning. If the student has a device to access the Internet as long as they can find a place with WIFI they can spend some time learning. The places currently are almost finite a park, a coffee shop, a salon, an airplane or train. The student is no longer restricted the classroom to spend time learning. Students can learn almost anytime/anywhere.
- Path: Because of digital learning with the interactive and adaptive software learning is not constricted according to the teaching method of the teacher. There are several options available so students can choose the one that best suits their learning method. The software provides teachers with real-time feedback so the teacher can adjust instructions to the students.

- Pace: Teachers have had to deal with the issue of students with different learning speeds for a long time and having to find a solution to this challenge for a long time, Digital Learning provides software that is interactive and adaptive to your lessons and students. The students can work at their own pace so the class isn't controlled by the slower student. Students are allowed to spend time on lessons that fits their learning needs

Moving at their own pace allows students to get maximum value from the lessons and avoids the stress from being behind and having to find a way to catch up. There is discipline required with the self-paced method. Students are not allowed the do the work when they want. They would be expected to make progress by doing the work and time and experience will provide a faster learning time.

Digital learning more than just using the hardware devices most students use at home such as laptops, tablets or smartphones to get lessons online. It involves learning tools with content and instruction,

Teachers help students to maintain their education by using technology tools to provide relevant deliver material for learning while monitoring the students and providing help when needed.

Digital learning is more than just providing students with the hardware. It also requires content and instruction.

- Technology: Technology is the tool that delivers content. It enables students to receive content. With hardware and Internet access together it is the tool that provides the instruction.

- Digital Content: Digital content is the material that students learn that is sent through technology. It is normally high quality academic material which is delivered through technology. It is what students learn. The content can be chosen from a diverse option list. It can be whatever you need for the instruction. It ranges from new, interactive software to video lectures to games.

- Instruction: Even digital learning needs Educators they are indispensable. Teachers might have to retire some of the tools, such as, white boards, chalk boards, and textbooks but will never eliminate the need for a teacher. Teachers will still be needed to provide guidance and help to make sure students learn and maintain their education path 


\section{A. How to choose digital resources for English classroom}

Teachers today are overwhelmed with technology tools, other digital resources, from varied materials from publishers to interactive and adaptive software available online on the web. The criteria is bountiful for picking the resources needed for a course [6]. These include:

- Teacher surveys and observes which materials are suitable for students; for example, ensure that students can access the materials on their device - smartphone, tablet, laptop, etc.

- Teacher surveys if the Internet connection is available in the classroom and students can use Internet to practice the lesson at home.

- Ensure that the application suggested to students is userfriendly because not every student can use complicated software of the application.

- Learning platform and learning website as learning and teaching resources always updates and may have new features. Teacher has to ensure to educate students about the changes and adjust the instruction to fit the new features.

The TPACK model by Mishra and Koehler [7] is recommended by the author to assist teachers to plan a lesson to be used in digital learnings. The model contains 3 elements. The elements are content knowledge, pedagogical knowledge, and technological knowledge.

- Content knowledge; e.g. teacher knows what a 'diphthong' is.

- Pedagogical knowledge; e.g. teacher knows how to teach students to pronounce word with 'diphthong'.

- Technological knowledge; e.g. technology can enhance the lesson to practice with an interactive exercise that provide students with guided language practice in using 'diphthong' when they pronounce the word correctly.

To choose digital resources for English classroom, always ensure the classes are based primarily on pedagogy, rather than being technology-led. If there is a technological issue during the online class, teacher should always have back up plan to assist students to continue their practice; for example, prepare alternative website as a homework instead of a live class.

\section{ONLINE COLLABORATION}

Online collaboration refers to people working together through online meeting tools or via collaborative application remotely [8]. The idea of collaborative learning is that students work together at the same time via online text documents or online meeting application; such as, Google Docs or Google Slides, Zoom or Google Meet for projects.

As weekend classes had a limited number of teachers to teach, so the obligation is only given to a few teachers who were responsible to prepare teaching material for the summer class. There were only a few teachers who use digital learning resources regularly, the rest were not ready to adapt their lessons to the changes.

The author assumed that it was an opportunity to manage alternative learning and teaching with digital and online collaboration. Unfortunately, the other teachers at the English department did not have enough time to prepare and adapt to the changes.

\section{Challenges on Using TeChNOLOGY IN THE ClassRoOM}

Scholars suggested that there were two factors that can cause the challenges; external and internal challenges to classroom technology [9].

External Challenges to Classroom Technology refer to access constraint, inadequate training, and the support constraint.

The access constraint happens when school does not prepare enough computers for teachers and students with stable Internet connection. If the teacher does not have adequate training related to new technology for the classroom, they will not be capable to use it effectively. One most important factor to facing challenges is that the support from school administrative toward technical support before, during, and after online classroom.

Internal challenges to classroom technology refer to teacher attitudes and beliefs, teacher resistance to technology in the classroom and teacher skills and knowledge.

Teacher should have a positive attitude and beliefs towards using technology in the classroom. Teacher should also have confidence in skills and knowledge. The school should propose solutions to increase teacher's acceptance of classroom technology by organizing a quality and practical training by experienced trainers.

Challenges to create and plan online class with time limitation Creating and planning online classes were absolute challenges for teachers who were not ready to use them. The problems were that teachers had to learn how to create and operate online tools during live lecture class, or they had to install new equipment and home environment to support during teaching from home. For some students, they don't have qualified equipment or learning devices to support online class, for example, an old model of smartphone and poor internet connection from their phone SIM Card. Not everyone has wi-fi at home to watch and listen from online material teachers prepared for them. The challenges were that teachers who can handle or have ability to use online teaching tools had to plan and create "how to" video to teach their colleagues as virtual training. It's very hard and too much struggle at the beginning because the policies came unexpectedly, but everyone had to follow the protocol. Therefore, most urgent plans were training and educating both teachers and students about living and working around the virus, including working and studying remotely. In this case, the solution for the challenges is to do a training on how to use digital resources for learning English for 
both teachers and students. Moreover, choosing suitable digital learning tools and user-friendly platform for the lesson that shifts from offline to online classroom is another way help teachers and students to pass the difficult time during the pandemic spread.

\section{CHOOSING DigitAl LEARNING TOOLS AND USER-FRIENDLY PLATFORM}

Choosing a user-friendly learning platform was also another challenge. Besides, choosing or creating learning resources an putting on the learning platform is more challenge. Suggestion to choose digital teaching and learning tools will be discussed as followed.

Suggested Digital Teaching and Learning Tools; YouTube, Quizlet, FlipGrid

To choose tools to create digital learning application, teachers can use YouTube to deliver lesson content and lecture videos. To assess students' learning outcome, teachers can use Quizlet and FlipGrid. The discussion about how to use them will be discussed next.

\section{Lesson Content and Lecture Tools; YouTube}

YouTube is still a powerful tools in English classroom. Google and YouTube launch new resources to help teachers and families educate students at home during the beginning of the pandemic. To operate the pronunciation class for this semester, the author chose videos from Youtube related to the contents of English pronunciation and Sound System course, then upload to Schoology. Students can easily to access the learning platform and watch the video without spending times searching for it. Teachers also recorded a series of video lectures explaining about each video both in Thai and English to clarify students' understanding throughout the learning content.

\section{Assessment Tools; Quizlet and FlipGrid}

There were two tools used to assess students' learning outcome after listen and watch the video lectures. They are Quizlet and FlipGrid.

Quizlet is an American online study application that allows students to study via learning tools and games. Quizlet provides flashcards, games and quizzes. There are both free and paid version for teachers to choose. Quizlet can be practice and assess tools. As during study about Phonetic Symbols, teachers can use Quizlet to quiz students if they can remember all the phonetic alphabet. After that they can use the same quiz to review and practice to fulfill where they missed during the quiz.

Flipgrid is a video discussion tool which students can share their responses through video with teacher and classmates. Flipgrid is one of a user-friendly teaching tools that can be utilized for all students' level and disciplines. Flipgrid joined with Microsoft and everything is free.
After students got all input from chosen video from Youtube and teacher's lecture video, students had to perform their pronunciation both words and sentences. FlipGrid helped students to record their voice and submit their response to the assignments easier than record a video and upload the file to the prepared platform, because some big file cannot be upload with low speed connection. FlipGrid also facilitated teachers to look at students' performance and grade them easier.

Suggested user-friendly platforms; Google Classroom vs. Schoology

The 2 user-friendly online learning platforms; Google Classroom and Schoology, will be discussed as followed.

There were several learning platforms to use, but the ones that works well for both teachers and students at the English Department were Google Classroom and Schoology. The author chose Schoology for the 2-month summer pronunciation class because Schoology integrates with other useful teaching tools, for example, Quizlet, FlipGrid, while Google Classroom does not provide a central to access all the tech tools used in the classroom, it's an additional tool that the teachers have to learn more how to operate it correctly.

Schoology does not integrate with Google Classroom, but teachers can use Google Application Tools with Schoology. Teachers can use Google tools and YouTube inside Schoology.

However, for most of the previous classes the author uses Schoology and Google Applications together to make the classes most effectively.

"Schoology Exchange forum" from Schoology.com explained about integrating Google and Schoology for "the perfect classroom combo". (Schoology Exchange Forum, 2020)

"Schoology has integrations with Google, allowing you build dynamic,

student-centered courses using Google tools, collaborating on Google

documents, and using Google Docs, Sheets, and Slides for assignments. "

\section{REFLECTIVE PRACTICE IN REFLECTIVE JOURNAL AS STUDENTS' FEEDBACK}

Beside using all digital tools to teach online, teachers have to make sure that students learn and achieve learning purposes of the course. The author use "reflective practice" [4] to get students reflection after learning online. So that teachers know what students struggle and problem to follow the lesson throughout the term.

The reflection prompts were open-ended, for example: What do you find most helpful in improving pronunciation? What was your major problem during practice pronunciation online? What tools or material you would like the instructor to prepare onto Schoology? Students were given detailed consent 
forms in the beginning of each class, explaining that their participation in the reflection journal would not affect their academic performance.

These are alternative ways to operate reflective practice in the classroom by Habib [10]. They are reflective journal, and group discussion. For this pronunciation class, here are suggestions.

\section{A. Online Reflective Journal}

Students can use reflective journal to record their thinking about all practice performance during practice their pronunciation both inside and outside the classroom. They can write their journal in Schoology where teacher prepares for them, or they can use blog to write the journal and submit the link through Schoology.

\section{B. Online Discussion Group}

1) Teacher-student \& student-student discussion group: Teacher can form a group with students or students can form a group to discuss online through meeting application, such as Zoom or Google meet. The topic they can discuss include their experience about pronunciation practice online. They can share problems they faced and how to solve them.

2) Mentor or homeroom teacher: Teachers can work with volunteer mentor from the department or homeroom teacher of each class to create an online discussion group. Then, ask students to join the group. The mentor and homeroom teacher will guide, ask questions, offers a different perspective and provides online resources with the instruction. Students can learn from their guidelines and resources, then compare their experiences and report to the class.

3) Professional learning experiences: Teachers can create an online discussion group for other students who has already had online learning experiences and invite students from the class to join the network. This way, students can share their experiences with peers and reflect their own, then report to the class.

\section{CONCLUSION}

Teaching online is not difficult for teachers who are familiar with digital learning strategies. But it will be a struggle for ones that have not used it regularly during the teaching routine. It was an opportunity to manage alternative learning and teaching with digital and online collaboration during the
COVID-19 pandemic even though some teachers were not ready to use it. It was challenging to find the way to shift regular class to online ones when students had to stay at home and teacher had to teach remotely. Educational technology seems the best solutions to the problems. In this case, the digital resources used in English pronunciation class were YouTube, Quizlet, and FlipGrid. The three applications combined and used effectively in Schoology as a user-friendly platform. Moreover, the reflective practice was used to get students' reflection toward online lesson throughout the course. The suggestion for further study can be survey research or action research about how students used digital resources and compare their achievements. Qualitative research can be constructed toward how students use all digital resources to practice their English pronunciation. Advantages and disadvantages of using each application should also be investigated.

\section{REFERENCES}

[1] WHO https://www.who.int/, 2019

[2] Ministry of Public Health of Thailand, COVID-19 Daily Updates Announcement. Retrieved from https://www.moph.go.th/, 2019.

[3] G. Stanley, Language with Technology: Ideas for Integrating Technology in the Language Classroom. Cambridge University Press, 2013

[4] T.S.C. Farrell, Reflective Practice in ELT: Reflective Practice in Language Education. Brock University, 2019.

[5] Florida Digital Learning (n.d.) What is Digital Learning? Retrieved from https://gosa.georgia.gov/what-digital-learning

[6] P. Sharma, How to select digital resources for use in your language classroom. World of Better Learning. Cambridge University Press, 2020 .

[7] P. Mishra, and M.J. Koehler, "Technological pedagogical content knowledge: A framework for integrating technology in teachers' knowledge," Teachers College Record, vol. 108, no. 6, pp. 1017-1054, 2006.

[8] G. Warren, What is Online Collaboration? Retrieved from https://www.lifewire.com/faqs-about-online-collaboration-23772501, 2020, August 18

[9] A.M. Johnson, M.E. Jacovina, D.E. Russell, and C.M. Soto, Challenges and solutions when using technologies in the classroom. In S. A. Crossley \& D. S. McNamara (Eds.) Adaptive educational technologies for literacy instruction (pp. 13-29). New York: Taylor \& Francis. Published with acknowledgment of federal support, 2016

[10] H. Habib, "A Study of Reflective Practice and its Role for Teachers," International Journal of Creative Research Thoughts (IJCRT), vol. 5, no. 4, pp. 944-947, 2017. 